Document downloaded from:

http://hdl.handle.net/10251/95284

This paper must be cited as:

Pérez-Martín, MÁ; Estrela Monreal, T.; Amo-Merino, PD. (2016). Measures required to reach the nitrate objectives in groundwater based on a long-term nitrate model for large river basins (Jucar, Spain). The Science of The Total Environment. 566:122-133.

doi:10.1016/j.scitotenv.2016.04.206

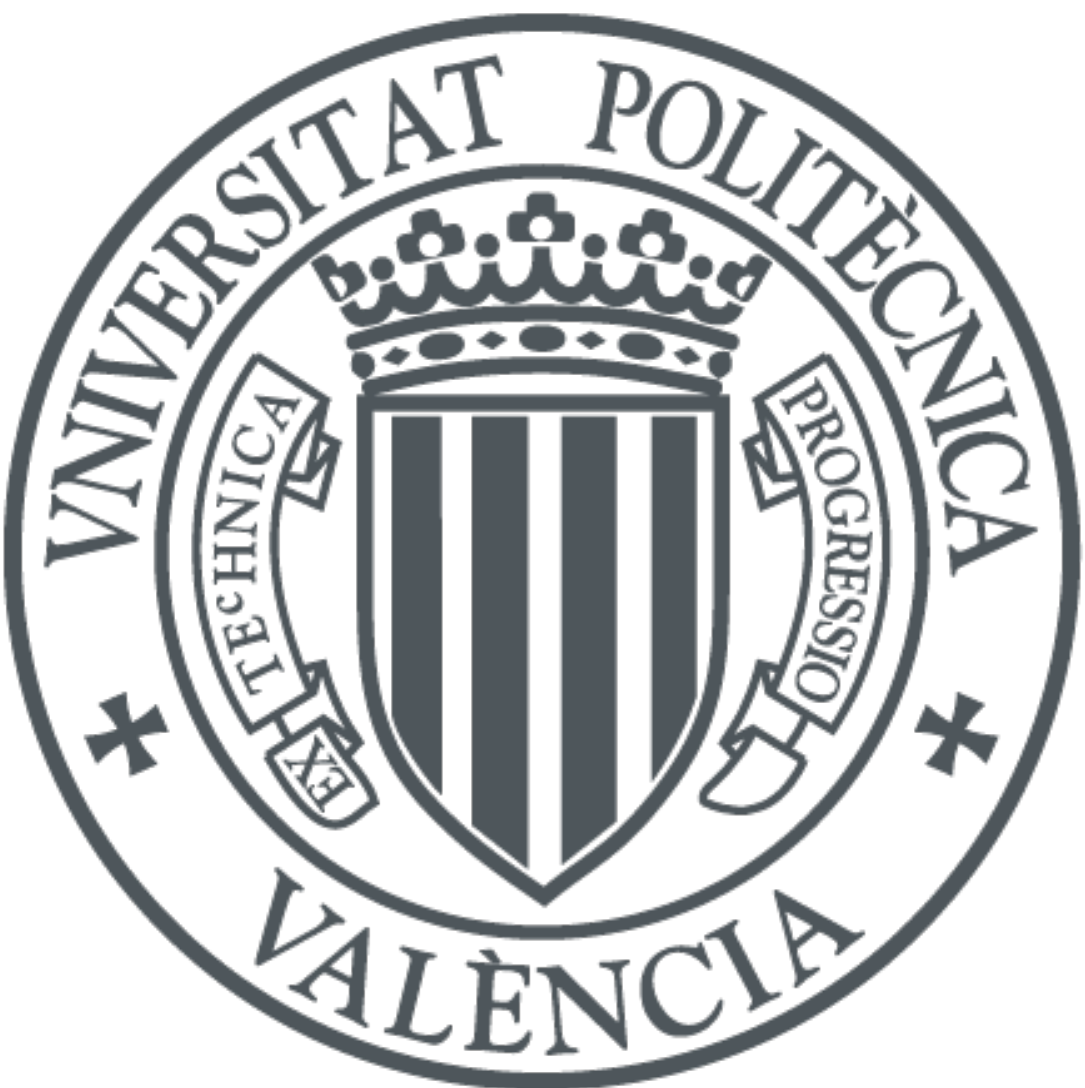

The final publication is available at

https://doi.org/10.1016/j.scitotenv.2016.04.206

Copyright Elsevier

Additional Information 


\title{
Measures required to reach the nitrate objectives in groundwater based on a long-term nitrate model for large river basins (Júcar, Spain).
}

\author{
$\underline{\text { Miguel A. Pérez-Martín }}^{{ }^{1}}$; Teodoro Estrela $^{2}{ }^{1}$; and Patricia del-Amo ${ }^{3}$ \\ ${ }^{1}$ Research Institute of Water and Environmental Engineering (IIAMA), Universitat Politècnica \\ de Valencia, Camino de Vera s/n, 46022, Valencia, Spain. * Tel.: +34 393879794 \\ ${ }^{2}$ Júcar River Basin Authority. Confederación Hidrográfica del Júcar (CHJ), Avd. Blasco \\ Ibáñez $n^{\circ}$ 48, 46010, Valencia, Spain. \\ ${ }^{3}$ Universitat Politècnica de Valencia, Camino de Vera s/n, 46022, Valencia, Spain. \\ E-mail addresses:mperezm@hma.upv.es \\ Keywords: Water Nitrate; Groundwater; Water Framework Directive; Large River Basin; \\ Mediterranean; Nitrogen Pollution.
}

\begin{abstract}
Nitrate pollution, primarily in groundwater $(\mathrm{GW})$, has been one of major water pollution problems in Europe over the last 30 years. Specially, Mediterranean areas (semi-arid zones) are more vulnerable to nitrate pollution, as in these areas a small excess of nitrogen produce higher nitrate concentrations than in more humid countries because the aquifer recharge is minor. A large number of GW bodies in the Júcar River Basin District (RBD) $\left(43.000 \mathrm{~km}^{2}\right)$, located in Spain, has nitrate concentrations above $50 \mathrm{mg} / \mathrm{L}$. The Water Framework Directive (WFD) sets out the goal of good status for the water bodies of the European Union, which also implies compliance with the Nitrates Directive.

The River Basin Authorities (RBAs) must define the measures needed to reach the environmental objectives in the River Basin Management Plans (RBMPs), considering the long time-lag of aquifers is decisive in the measures effectiveness. By means of nitrogen cycle simulation in the river basin district and with the help of the monthly distributed PATRICAL model, the Júcar RBA has defined the measures to be applied and the exemptions to reach the objectives in GW in relation to nitrate pollution. Both, model and methodology are useful for other river basins to define measures.
\end{abstract}


The total nitrogen inputs in the Júcar RBD amounts to $180,000 \mathrm{tN} /$ year, which represents a nitrogen surplus of 80,000 $\mathrm{tN} /$ year and a pressure of $58.5 \mathrm{kgN} /$ year/ha-crop. Around $3 / 4$ of GW bodies have currently the good status while the remaining of GW bodies could reach the good status during following hydrological planning cycles through the implementation of modernized irrigation systems that include fertigation the use of fertilizers in the water for irrigation-. The implementation of this scenario involves increasing efficiency in fertilizer application, in order to reduce nitrogen losses from slightly under a half to less than $1 / 3$. 


\section{Introduction}

Water pollution by nitrate produces negative impacts on human and environmental health (Rios et al., 2013). Exposure to higher concentrations of nitrates or nitrites has been associated with increased incidence of stomach and gastric cancer in adults, and possible increased incidence of brain tumours, leukaemia, and nasopharyngeal (nose and throat) tumours in children (USEPA, 2007). Also, the main health effect for children is the "blue baby syndrome" (methemoglobinemia), seen most often in infants exposed to nitrate from drinking water (USEPA, 2007). In aquatic ecosystems, elevated concentrations of nitrate can help to produce eutrophication.

The global increase in nitrogen $(\mathrm{N})$ use as chemical fertilizer (Heffer, 2012) or as organic input from large livestock population, produced a general increase of nitrate concentration in surface water (SW) (Aquilina et al., 2012) and groundwater (GW), which, in recent decades, has become a major environmental concern (Galloway et al, 2004; Vitousek et al, 1997). Many regions have significantly altered the global nutrient cycle (Ferrant et al., 2011), such as the following: Upper Mississippi River (Houser and Richardson, 2010), Northeastern United States (Howarth et al., 1996; Berka et al., 2001; Boyer et al., 2002), New Zealand (Gillingham and Thorrold, 2000; Monaghan et al., 2005), Ireland (Neill, 1989; Watson and Foy, 2001), United Kingdom (Webb and Walling, 1985; Reynolds and Edwards, 1995; Whitehead et al., 2002b), Norway (Blecken and Bakken, 1997), France (Ruiz et al., 2002; Molenat et al., 2002; Martin et al., 2004) and Portugal (Pacheco and Sanches-Fernandes, 2016). Specially, nitrate concentration reaches higher values in GW, thus there are great extensions of $\mathrm{GW}$ polluted by nitrate in the world: in the USA, Canada, Japan, Europe and Australia (Deng et al., 2011), and also northeast China (Huan et al., 2012) and Yellow River (Shen et al., 2011).

The US Protection Agency (US EPA) has established a maximum contaminant concentration of $10 \mathrm{mg} / \mathrm{L} \mathrm{NO}_{3}-\mathrm{N}$ (USEPA, 2000) or $45 \mathrm{mg} / \mathrm{L} \mathrm{NO}_{3}$ for drinking water while the maximum acceptable concentration of nitrate for potable water according to the World Health Organization (WHO), is $50 \mathrm{mg} / \mathrm{L} \mathrm{NO}_{3}$ or $11.3 \mathrm{mg} / \mathrm{L} \mathrm{NO}_{3}-\mathrm{N}$. The purpose of both the EU Nitrates Directive $(\mathrm{EC}, 1991)$ and the Groundwater Directive GWD- (EC, 2006), according with the Water Framework Directive -WFD- (EC, 2000), 
is to keep nitrate concentration in GW below a threshold of $50 \mathrm{mg} / \mathrm{L}$. Once a water source is contaminated, the costs of protecting consumers from nitrate exposure can be significant. Nitrate cannot be removed by conventional drinking water treatment processes; its removal requires additional, relatively expensive treatment units (USEPA, 2004).

Due to the long time-lag in the groundwater system, it could take decades for leached nitrate from the soil to discharge into freshwaters (Wang et al. 2012; Wang et al 2013 and Wang et al 2016). Besides, the intercrop periods were identified as critical periods for nitrate leaching (Dupas et al., 2015) and total annual precipitation and catchment connectivity are important for nitrate-N transport, with fluxes in a wet year roughly doubling that recorded in a dry year (Outram et al., 2016).

Models can help better understand the nitrate pollution in SW and GW in a large river basin. They are needed to understand direct interactions between land cover and water pollution by nutrient in space and time (Ferrant et al, 2011), and also, to assess the effectiveness of the implementation of programmes of measures.

Models are widely used to simulate $\mathrm{N}$ cycle and $\mathrm{N}$ transport at plot scale or small catchment scale (Brisson et al., 1998; Vanclooster et al., 1995) and to determine the nitrate concentration in river and the N-exportation rates (Ferrant et al., 2011; Zhang et al., 2016). Large-scale catchments have been modelled by integrating GIS or decision support modules (Lake et al., 2003; Lasserre et al., 1999; Lunn et al., 1996) and it has been suggested that the appropriate use of these different model types will depend on the scale of investigation (Quinn, 2004). Moreover, in most of these models, the GW compartment has a limited role and may even be lacking in GIS or statistical models (Aquilina et al., 2012); thus, in studies of GW at regional scale, it is usual to apply the approach based on the vulnerability assessment, such as the application of the DRASTIC model (Huan et al., 2012; Martínez-Bastida et al., 2010).

In Ferrant et al, (2011) it is indicated that several models (Breurer et al., 2008) have coupled an hydrological model and a crop model to study the interactions between agricultural practices and catchment physical characteristics on the dynamics of $\mathrm{N}$ in streams (Mangold and Tsang, 1991; Vachaud et al., 1993; Styczen and Storm, 1995; Lunn et al., 1996; Beaujouan et al., 2002; Whitehead et al., 2002a; Wade et al., 2004; 
Liu et al., 2005; Flipo et al., 2007). Also, SW and GW models are coupled to simulate nitrate in GW such as, SWAT-MODFLOW-MT3DMS models to simulate a large aquifer of $11600 \mathrm{~km}^{2}$ in India (Narula and Gosain, 2012). Hydrogeological models GROWA-DENUZ/WEKU, were coupled to the agro-economic model RAUMIS to define measures to reach the nitrate objective in SW and GW in the Federal State of North Rhine Westphalia in Germany (Kuhr et al, 2015). Lumped-parameters models were developed to simulate future nitrate conditions in the Gaza Coastal Aquifer (Hajhamad and Almasri, 2009) and, also, to determine the best management options to reduce nitrate concentration in GW.

While mitigation programs have been developed to reduce $\mathrm{N}$ input to the $\mathrm{SW}$, the effects of such attempts remain relatively limited (Aquilina et al., 2012); there is a consensus that more efforts are required to reduce nitrate concentrations in rivers and aquifers. River Basin Authorities and Nacional/Regional Governments must apply new approaches and strategies to reverse this trend and to recover the status of the aquifers. The Water Framework Directive (WFD) requires no further deterioration as well as a progressive reduction of pollution to reach the good status in the GW bodies in the year 2015. Also, the WFD indicates that in case of specific conditions as for instance technical feasibility, disproportionately expensive or natural conditions -such as long time-lag in the groundwater system which does not allow timely improvement in the status of the water body-, the deadline may be extended (exemptions in following 6year period, 2021, 2027 ...). The River Basin Management Plan (Annex VII of WFD) must establish the specific nitrate concentration in each GW body for the year 2015 the extended deadlines foreseen and the measures to achieve these nitrate objectives.

In Europe -EU-27-, the averaged pressure (nitrogen surplus) is around $60 \mathrm{kgN} / \mathrm{ha}$ of crops (ha-crop) (Leip et al. 2011). Spain has lower nitrogen pressure than the average, around $50 \mathrm{kgN} /$ ha-crop, and much lower than other countries, such as the Netherlands (250-300 kgN/ha-crop), Belgium (150-200 kgN/ha-crop) or Denmark (130-150 kgN/hacrop). However a large number of aquifers in Spain, mainly in the semiarid areas, are polluted by nitrate. This is produced because the aquifer recharge is minor in the semiarid areas of Spain than in other areas with humid climate, and thus, the same nitrogen pressure (or even minor pressures) over the aquifers, produces higher nitrate 
concentrations. For this reason, the Spanish Mediterranean areas are more vulnerable to nitrate pollution than other areas with humid climate.

In this paper, it is described how the Júcar River Basin Management Plan (RBMP) establishes, in a scientific and rigorous manner, the exemptions (mainly deadlines) and measures required to reach the objectives in relation to nitrate pollution in the GW bodies, taking in account the long time-lag of watersheds and aquifers. The methodology presented is common to the entire territory of Spain and it is based on the application of a distributed hydrologic and water quality simulation model, the PATRICAL model. The hydrologic module, its formulation and application to the Júcar River Basin District (RBD), is described in Pérez-Martín et al. (2014), and the nitrate module (formulation and application) is presented here. The methodology has two steps: 1) model calibration to the observed data; 2) nitrate simulation for three future scenarios with different degrees of implementation of mitigation measures. The main contributions of this manuscript are: 1) presents a new nitrate transport model for large river basins that is distributed, parsimonious (reduced number of parameters) and includes SW, GW and their interactions; 2) presents a methodology developed by the Júcar RBA to determine the measures required to recovery aquifers, and the year that it is produced, taking in account the long time-lag of aquifers; 3) the model and the methodology presented is applicable to other river basins in Europe that are currently working in establish the nitrate concentration objectives in the GW bodies and the measures - and deadlines - required to recovery the aquifer status, as evidenced by subsequent application to the entire Spanish territory.

The effect of these three fertilizer application scenarios on nitrate concentrations has been assessed with the simulation model. The scenarios are: 1) baseline scenario, which corresponds to maintaining the current fertilization; 2) optimal scenario, which involves the application of the nitrogen optimal dose and includes the fertilizers in the drip irrigation; this requires a strong economic investment through the application of techniques such as fertigation, which include the use of fertilizers in the drip irrigation; 3) trend reversal and improvement scenario, which is an intermediate stage between the two previous ones and includes the development of the action plans defined in current vulnerable areas; this is the more plausible scenario in the short to medium term. 
The PATRICAL model simulates the nitrate cycle in medium/large basins, as it is the case of the entire Spanish territory $\left(500,000 \mathrm{~km}^{2}\right)$ where it is applied (Pérez-Martín et al. 2012). The model uses the water flows and water storages obtained by its hydrological module in altered conditions by human activities. The model obtains the monthly nitrate concentrations in aquifers and surface flows. This model has only three parameters to simulate the nitrate transport in the entire river basin, thus it can be stated that the model is very parsimonious. The results obtained with this methodology are: the GW bodies that are foreseen to reach the objective in the year 2015 (nitrate concentration lower than $50 \mathrm{mgNO}_{3} / \mathrm{L}$ ) and the $\mathrm{GW}$ bodies that require extended deadline until next water planning cycles: 2021, 2027, 2033 or 2039. Also, other valuable results are the definition of the measures needed to reach these objectives in each GW body. 


\section{Methods and Data Sets}

\subsection{The Simulation Model}

The PATRICAL model is a large-scale (medium/large RBs), conceptual, monthly and spatially distributed (grid $1 \times 1 \mathrm{~km}^{2}$ ) water balance and water quality model (for multidecadal periods 50-100 years). The description of the hydrological model -components, water storages and fluxes and hydrological parameters- and its calibration and application to the Júcar RBD- is addressed in Pérez-Martin et al. (2014). The nitrate module has three storages in each cell (i.e. 1 x $1 \mathrm{~km}$ ), (Fig 1c): 1) Soil Storage, where nitrogen is included in the soil moisture. 2) Unsaturated Zone, between the root zone and the GW level. 3) Aquifer, which corresponds with the saturated zone, where a complete mixing of substances in water is considered. The model has the following modules (Fig. 1c and formulation in the Appendix): 1) Nitrogen balance on soil, 2) Nitrogen balance on unsaturated zone, 3) Nitrogen balance in the aquifer, 4) Routing Module and River Losses, and 5) Groundwater Transfer Module.

In this model, point source (PS) and non-point source (NPS) pollution are incorporated. PS pollution comes mainly from wastewater treatment plants from urban and industrial areas and it is transported directly by surface runoff. NPS pollution - nitrogen surplus (Fig. 1a)-, comes mainly from fertilizers, manures and deposition. NPS pollution is located in soil and is carried by water, as nitrate, by surface runoff and infiltration into the aquifer (Fig. 1b).

The nitrogen surplus is retained in soil (Fig. 1c), where volatilization and the water transport is produced. Nitrate is carried by surface runoff to the rivers and by infiltration to the unsaturated zone. Nitrate is retained in the unsaturated zone, where the amount retained depends on the unsaturated thickness, which is the difference between surface and the monthly simulated GW level. The nitrate in the unsaturated zone is washed out by deeper infiltration into the aquifer. The aquifer is considered as an aggregate element and GW discharges represent the nitrate outputs of the aquifer. Nitrate from surface runoff and GW discharges, is routed into the river. Finally, nitrate transported by transfers between groundwater bodies and river losses, is computed. 
Only three parameters with a unique value for the entire basin are defined in the model: 1) de-nitrification constant for a long stay of nitrate in soil $(k d e n$, dimensionless $[0, \infty])$, which defines the volatilization rate of the nitrogen stored in soil; 2) nitrate transfer coefficient in soil $(\mathrm{ks}$, dimensionless $[0, \infty])$, which determines the facility of water to wash out the nitrate from soil and thus the amount of nitrate retained in soil; and 3) nitrate transfer coefficient in the unsaturated zone $\left(k u z, \mathrm{~mm}^{-1}[0, \infty]\right)$, which represents the facility of water to wash the nitrate from the unsaturated zone.

The sensibility analysis shows that high values of $k$ den $(>5)$ imply that all the nitrogen will be volatilized in the next month, while the 0 value implies that there is no nitrogen volatilization. Low values of $k s$ increase the amount of nitrogen retained in soil while high values $(>3)$ produce a rapid wash of nitrate from soil. Low values of kuz mean that the nitrogen needs a long time to reach the aquifer, high values $(>1)$ imply that all the nitrogen reach the aquifer in less than a year.

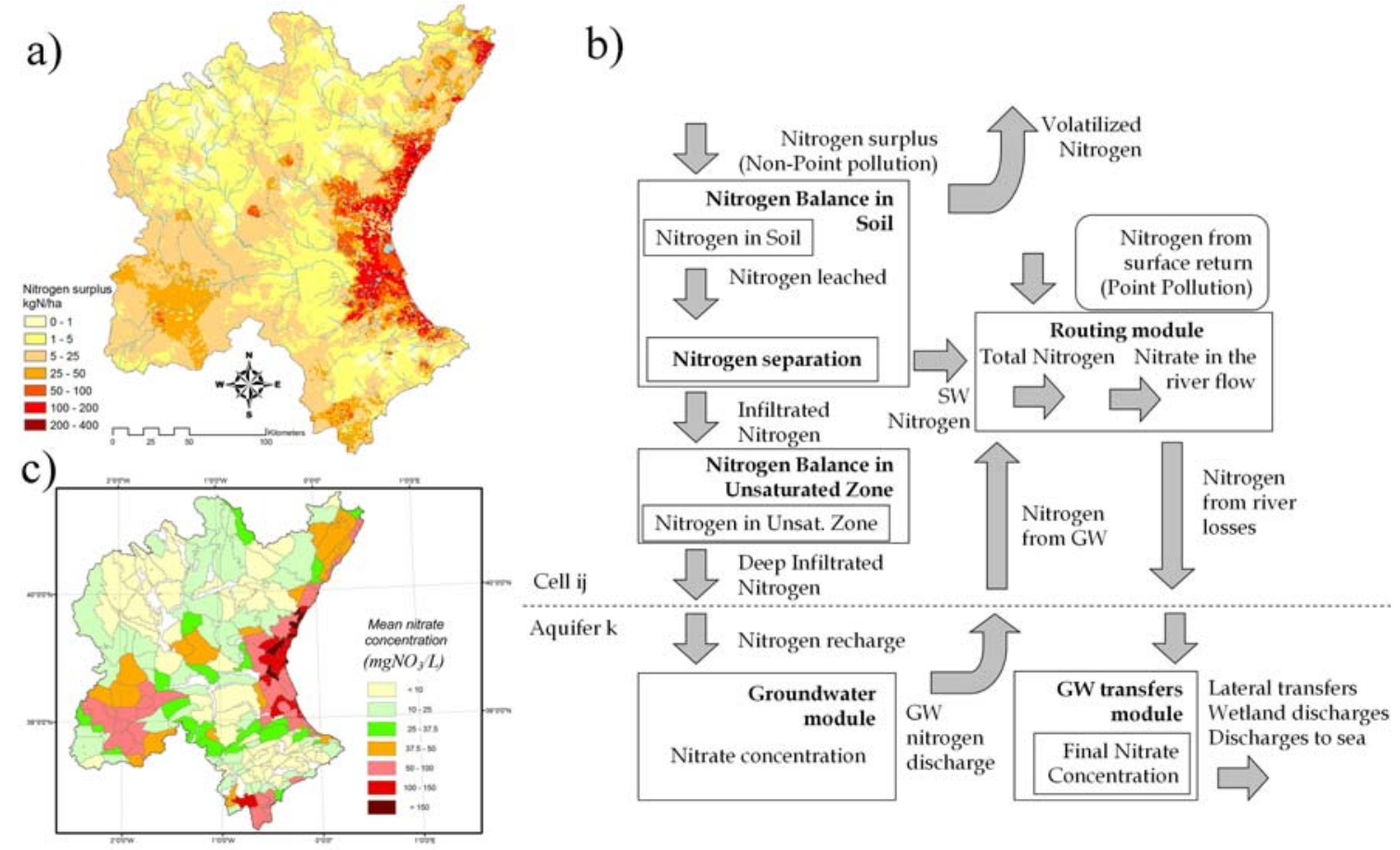

Fig. 1. a) Distributed nitrogen surplus (kgN/ha) and b) simulated nitrate concentration in groundwater $\left(\mathrm{mgNO}_{3} / \mathrm{L}\right)$ and c) structure and variables of the nitrate module of PATRICAL model. 


\subsection{The Júcar River Basin District}

The Júcar River Basin District (RBD) $\left(43,000 \mathrm{~km}^{2}\right)$ is located on the Mediterranean side of the Iberian Peninsula (Fig. 2a). In the Júcar RBD, there are $90 \mathrm{GW}$ bodies defined. A GW body is formed by one or more aquifers, and it is an administrative delimitation of GW. In the model, a GW body can be divided in various sectors, corresponding to the aquifers delimitation or to the different behaviour detected in different parts of the GW body. The model includes the simulation of more than 200 sectors in this river basin (Fig. 2b). A further description of the Júcar RBD is included in Ferrer et al. (2012) and Pérez-Martín et al. (2014).

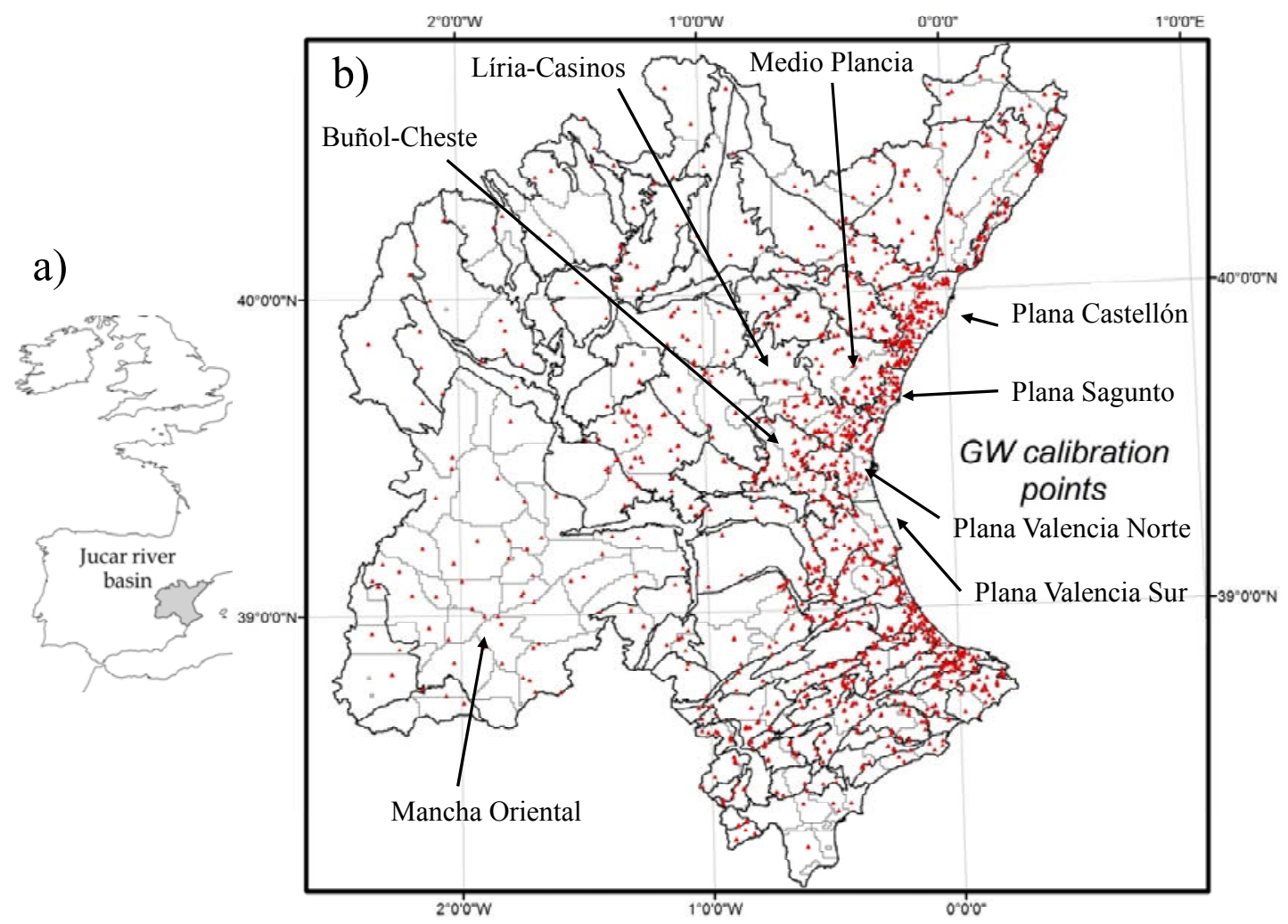

Fig. 2. a) Júcar RBD location b) GW and Sector delimitation and nitrate GW network.

Nitrogen surplus comes from the annual balance of nitrogen in soil at municipal level for the period between the years 2000 and 2011 (MARM, 2014). The mean balance in the Júcar RBD for the period 2007-2011 (Table 1) shows that $80 \%$ of inputs comes from inorganic/organic fertilizers $(57 / 13 \%)$ and atmospheric deposition (10\%), while harvest (crops and woods) and volatilization represents nearly $90 \%$ of the outputs. 
Inorganic fertilizers are the major input of nitrogen in the river basin, representing 57\% thereof. Atmospheric deposition is associated to the atmospheric volatilization produced in the nearest area, so it also depends on the total nitrogen input produced in the nearest area.

The NPS pollution, i.e. the nitrogen surplus, is around 80,000 $\mathrm{t}$ of Nitrogen per year ( $\mathrm{tN} /$ year) and it represents $44 \%$ of the total nitrogen inputs $(181,000 \mathrm{tN}$ in Table 1$)$, which produces a mean pressure of $58.5 \mathrm{kgN} / \mathrm{ha}$-crop. The global pressure related to the entire extension of the Júcar RBD is $18.5 \mathrm{kgN} / \mathrm{ha}$.

\begin{tabular}{|c|c|c|c|c|c|c|c|}
\hline Inputs & tN & rel & kgN/ha-crop & Outputs & tN & rel & kgN/ha-crop \\
\hline Inorganic Fertilizers & 103,060 & 0.57 & 75.9 & Crop Harvest & 58,856 & 0.58 & 43.3 \\
\hline Organic Fertilizers & 23,932 & 0.13 & 17.6 & Wood Harvest & 15,380 & 0.15 & 11.3 \\
\hline Atmospheric Deposition & 18,766 & 0.10 & 13.8 & Stubble Burning & 6,235 & 0.06 & 4.6 \\
\hline Nitrogen from Urban Waste & 12,769 & 0.07 & 9.4 & Pasturages & 1,750 & 0.02 & 1.3 \\
\hline Nitrogen in Water & 8,341 & 0.05 & 6.1 & Fertilizers Volatilization & 16,794 & 0.16 & 12.4 \\
\hline Livestock Manures & 7,715 & 0.04 & 5.7 & Pasturages Volatilization & 1,421 & 0.01 & 1.0 \\
\hline Biological Fixation & 5,202 & 0.03 & 3.8 & Fertilizers Denitrification & 1,119 & 0.01 & 0.8 \\
\hline Seeds & 1,563 & 0.01 & 1.2 & Others Denitrification & 212 & 0.00 & 0.2 \\
\hline & & & & Pasturages Denitrification & 114 & 0.00 & 0.1 \\
\hline TOTAL & $\mathbf{1 8 1 , 3 4 8}$ & $\mathbf{1 . 0 0}$ & $\mathbf{1 3 3 . 5}$ & TOTAL & $\mathbf{1 0 1 . 8 7 9}$ & $\mathbf{1 . 0 0}$ & $\mathbf{7 5 . 0}$ \\
\hline Surplus & & & & & $\mathbf{7 9 . 4 6 9}$ & $\mathbf{0 . 4 4}$ & $\mathbf{5 8 . 5}$ \\
\hline
\end{tabular}

Table 1. Averaged 5-year nitrogen balance in soil in the Júcar RBD for the period 2007-2011.

Nitrogen surplus at municipal level are spatially distributed within the municipality by means of the land use map (Corine Land Cover: CLC, 2000). Higher values are located mainly inside major agricultural areas (Fig. 1a) such as near the Mediterranean Sea (50 $200 \mathrm{kgN} / \mathrm{ha}$ ) and the Eastern Mancha Aquifer (25 kgN/ha). 


\subsection{Model Calibration and Validation}

The model runs from October 1970 until September 2012 and it requires hydrometeorological data, described in Pérez-Martín et al. (2014), and the nitrogen surplus data generated in the river basin. The nitrogen surplus data comes from the municipal nitrogen balance (described in section 2.1) for the period 2000-2011, and for the rest of the simulation period corresponding to previous years (1970-1999), nitrogen surplus is obtained combining the municipal balance (2000-2005) with the evolution of the global nitrogen use in Spain from 1970 to 2005.

The model is calibrated with nitrate data from GW network and it is validated with the GW bodies status evaluation made by the Júcar RBMP (CHJ, 2015). There is a large amount of available data: 7658 samples, from January 2000 to October 2013, distributed in $1874 \mathrm{GW}$ gauging stations in the Júcar RBD (Fig. 2b). The average number of data by station is 4 , less than 200 stations have more than 10 available data, and only 4 stations have more than 20 available samples. The large amount of available data allows determining with a great deal of certainty, the current status of the GW bodies. However, there is a reduced number of check points with insufficient data to determine historical trends or the variability of the processes involved.

Model performance was assessed using a double criteria approach: 1) a visual inspection of the model results in all the aquifers modelled with the observed data (some examples in Fig. 3), and 2) fitting the average nitrate concentration simulated in last years (oct-2005 to sep-2013) in each aquifer, to the mean nitrate concentration of the all samples available in each aquifer in the same period (Fig. 5). The fitted values of the parameters for the entire watershed are: $k d e n$ (dimensionless) $=0.05, k s$ $($ dimensionless $)=3.0$ and $k u z\left(\mathrm{~mm}^{-1}\right)=10.0$. Only three numerical values determine the nitrate behaviour in the entire river basin, so this provides a great robustness to the model.

Nitrate concentrations over the last years are stabilized in all the aquifers. The model results are included in the range of the observed data in different points of the aquifers (3 observed points in Fig. 3.). There are high differences between data observed in 
different points of the same aquifer (Fig. 3a and Fig. 3f) and also between different samples of the same point (obs. 1 in Fig. 3a and obs. 3 in Fig 3e).
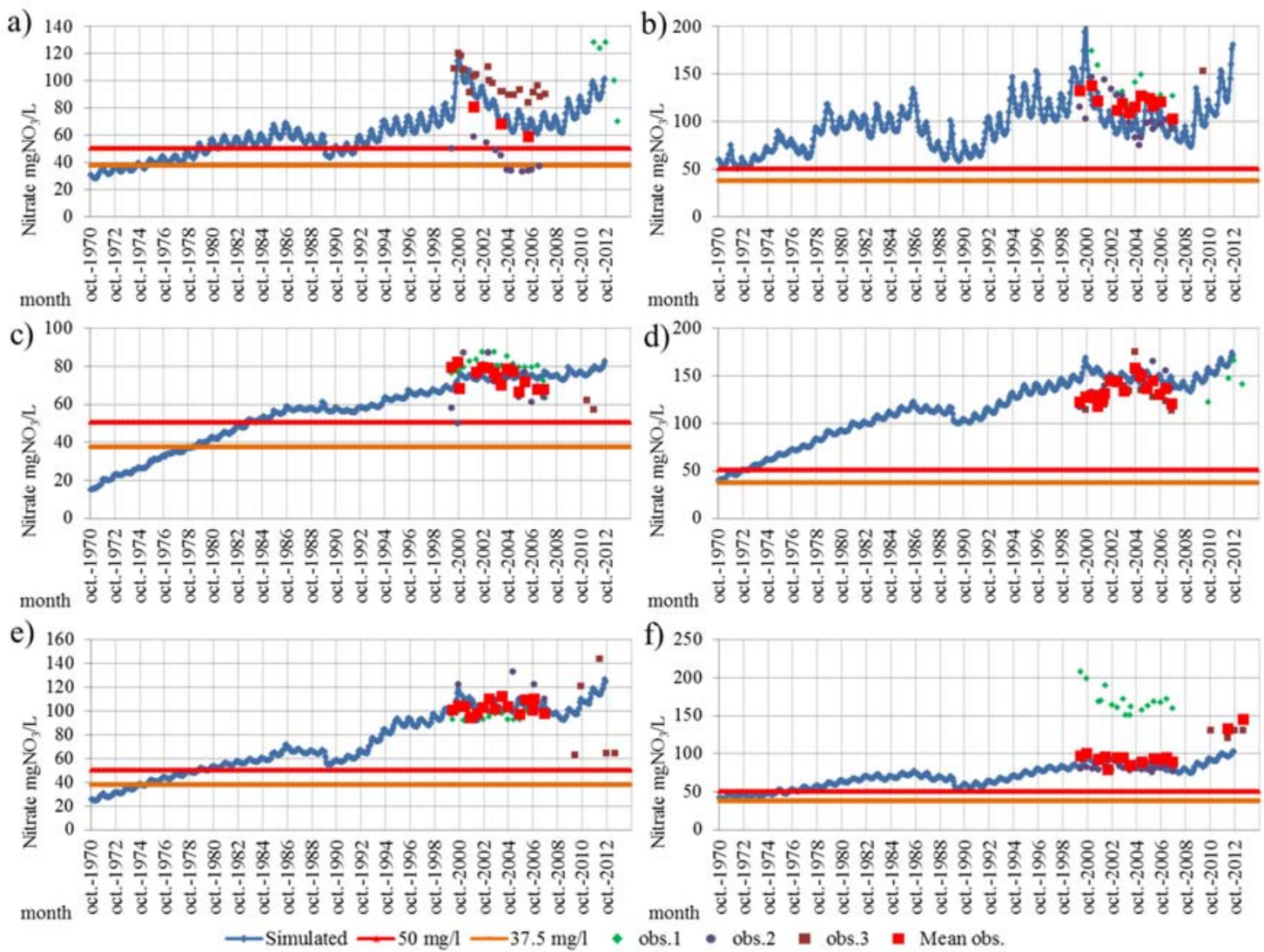

Fig. 3. Nitrate concentration $\left(\mathrm{mgNO}_{3} / \mathrm{L}\right)$ simulated and observed, including data of 3 observed points in the aquifer and the mean values of the all observed data, in different aquifers in the Júcar RBD: a) Plana de Castellón, b) Plana de Sagunto, c) Medio Palancia, d) Liria-casinos, e)

Plana de Valencia Norte and f) Plana de Valencia Sur.

A multi-year variability in nitrate concentrations is detected in model results, which is also confirmed with the observed data of Plana de Castellon and Plana de Sagunto (Fig $3 \mathrm{a}$ and $\mathrm{b})$. In both cases, observed nitrate concentrations decreased from 110 and $200 \mathrm{mgNO}_{3} / \mathrm{L}$ respectively in fall of 2000 , to 70 and $100 \mathrm{mgNO}_{3} / \mathrm{L}$ in summer of 2006. In the model, the multi-year variability depends on the annual amount of water that infiltrates into the aquifer and the unsaturated zone thickness. The aquifer Medio Palancia (Fig. 3c) has the major thickness (around $100 \mathrm{~m}$ ) of the cases presented, so nitrate concentrations -around $80 \mathrm{mgNO}_{3} / \mathrm{L}$ - have more long time-lag than the rest of cases (thickness around 30 m, Fig. 3). 
A strong convective rainfall was produced near the coast in October 2000. This rainfall carried a large amount of nitrate from soil and the unsaturated zone to the aquifers, so nitrate concentration strongly rose in this month in the aquifers. Over the next months/years the nitrate concentration in the aquifers will be declining, because soil and unsaturated zone (without nitrogen) is retaining the new nitrogen applied in the river basin.

The years 1989, 1990 and 1991 were three consecutive very wet years (Fig. 4a). During this period the model simulates a reduction in nitrate concentration in the aquifers (no observed data is available in this period). Similarly during the dry periods (1980-1987, 1992-1999 and 2009-2011) the descending stretches of standardized accumulated monthly deviation recharge observed in Fig. 4b) are associated to increases in the nitrate concentration (Fig. 3).
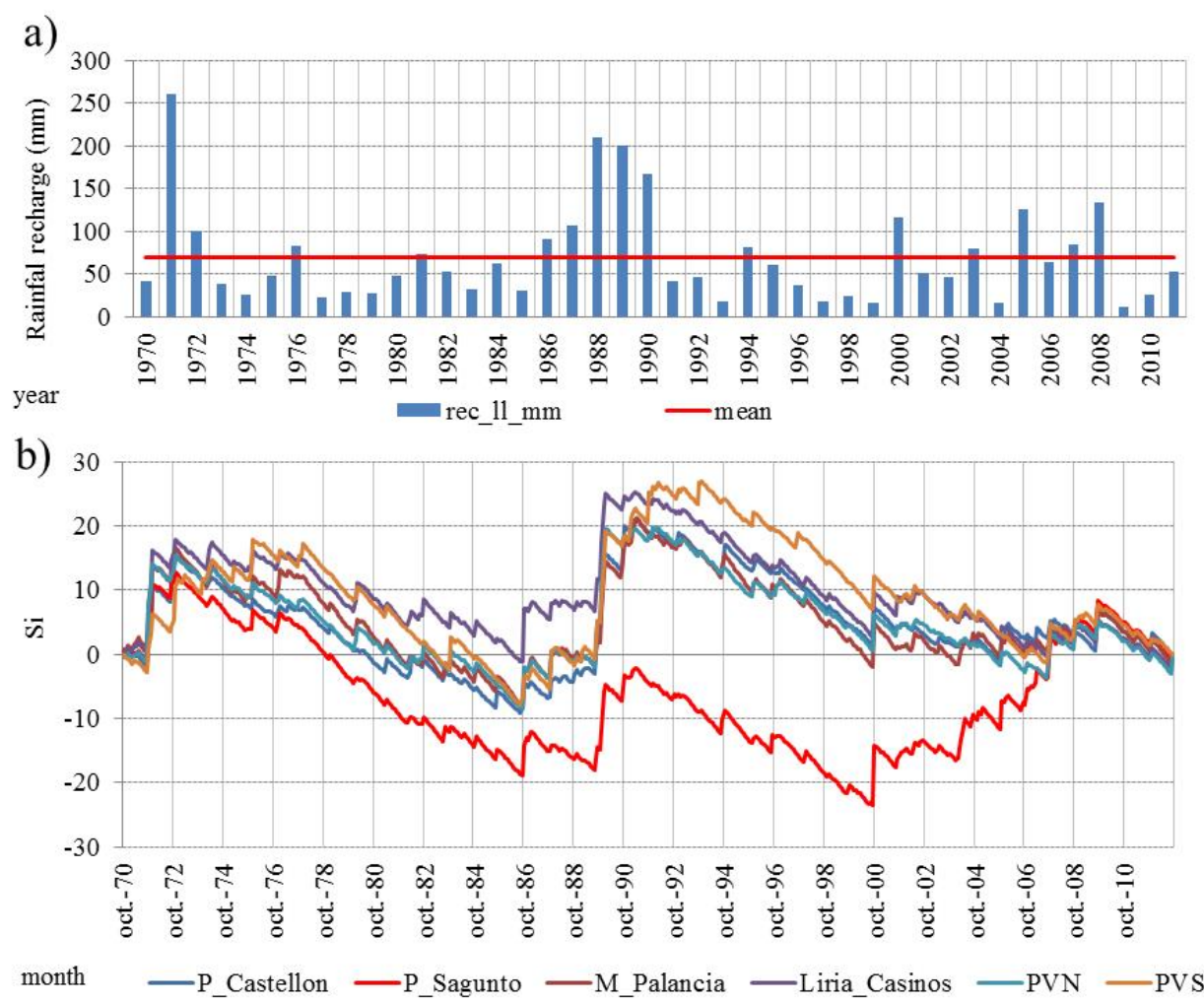

Fig. 4. a) Annual rainfall recharge (mm) near the coast in the Júcar RBD and b) standardized accumulated monthly deviation recharge (dimensionless).

Model is also calibrated fitting the average nitrate concentration simulated in the years (oct-2005 to sep-2013) in each aquifer to the mean nitrate concentration of all the 
samples available in each aquifer in the same period (fully mixed hypothesis are used to simulate the nitrate behaviour in the aquifers). Moriasi et al. (2007) indicates that in general, model simulation can be judged as satisfactory if Nash-Sutcliffe efficiency (NSE) $>0.50$ and if percent bias (PBIAS) $\pm 25 \%$ for streamflow, PBIAS $\pm 55 \%$ for sediment, and PBIAS $\pm 70 \%$ for $\mathrm{N}$ and $\mathrm{P}$. In this work, the NSE cannot be evaluated adequately due to the reduced number of available data along the time in the same point, so only the PBIAS is used to judge the model performance. In this case, the model has a very good performance (PBIAS $\pm 25 \%$ ) in $27 \%$ of the aquifers, good or very good performance (PBIAS $\pm 40 \%$ ) in $73 \%$ of the aquifers, satisfactory (or better) performance (PBIAS $\pm 70 \%$ ) in $88 \%$ of the aquifers and unsatisfactory performance in $12 \%$ of the aquifers. The correlation coefficient between average simulated and average observed data in each aquifer is $R=0.84$ (Fig. 5). As regards to aquifers with higher nitrate concentration, observed data greater than $50 \mathrm{mgNO}_{3} / \mathrm{L}$ or close to that value $(>35$ mgNO3/L), show a correlation coefficient between observed and simulated values of $\mathrm{R}=0.63$.

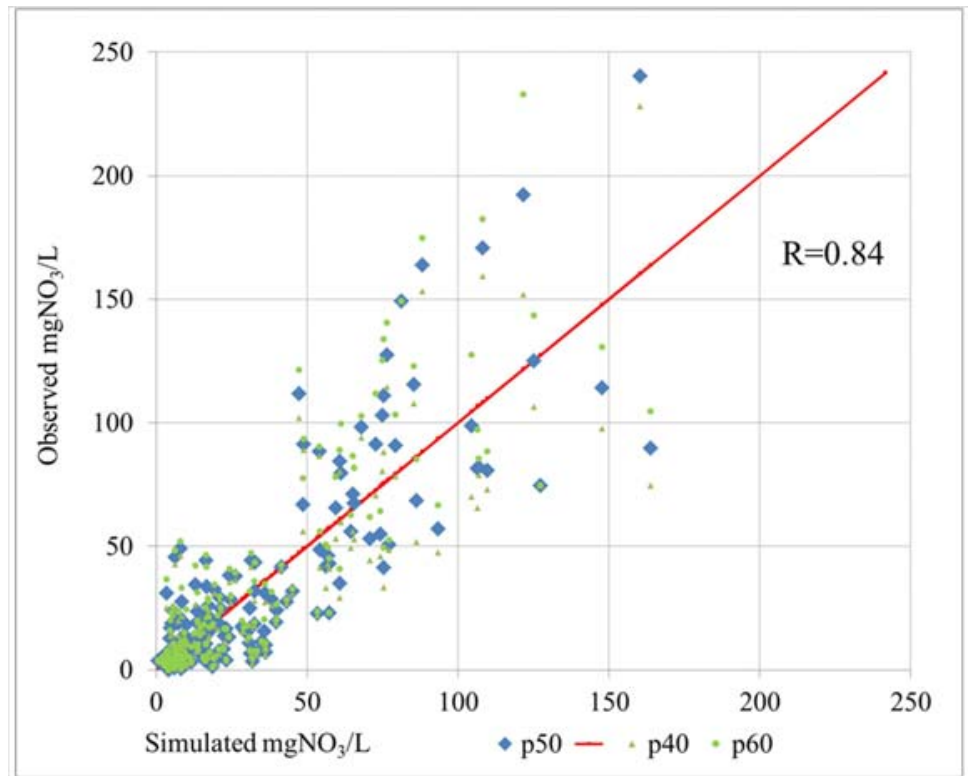

Fig. 5. Mean nitrate concentration $\left(\mathrm{mgNO}_{3} / \mathrm{L}\right)$ observed (and percentiles 40 and 60 -p40, p60) and simulated in each aquifer.

Model results validation of the $90 \mathrm{GW}$ bodies was made with the chemical status assessment made by the Júcar RBMP (CHJ, 2015). This official assessment is made according to the criteria established in the GWD (EC, 2006), and is based on the 
chemical GW network, assuming a representative weight to each control point located in the same GW body. High nitrate concentrations are located in areas near the coast and in the Mancha Oriental Aquifer (Fig. 6a); these areas are officially assessed in NotGood status by the Júcar RBMP (Fig. 6b). Minor discrepancies are found between model results and the official assessment. These discrepancies are located in four GW bodies without intensive agriculture and low nitrogen pressure (Fig. 6b) and a detailed analysis is developed in these four GW bodies. In three of them -"Javalambre Occidental", "Lezuza-El Jardín" and "Arco de Alcaraz"- the GW network is clearly not representative of the GW body global behaviour. Finally, there is only one case, "Almansa" GW body, wherein it is not clear if discrepancy is related to model limitations or rather to the lack of representativeness of the observed data. The great concordance between chemical status and model results, and also, the detailed analysis that justifies those discrepancies are mainly due to the lack of representativeness of the data network and indicates the great robustness and reliability of the proposed model.
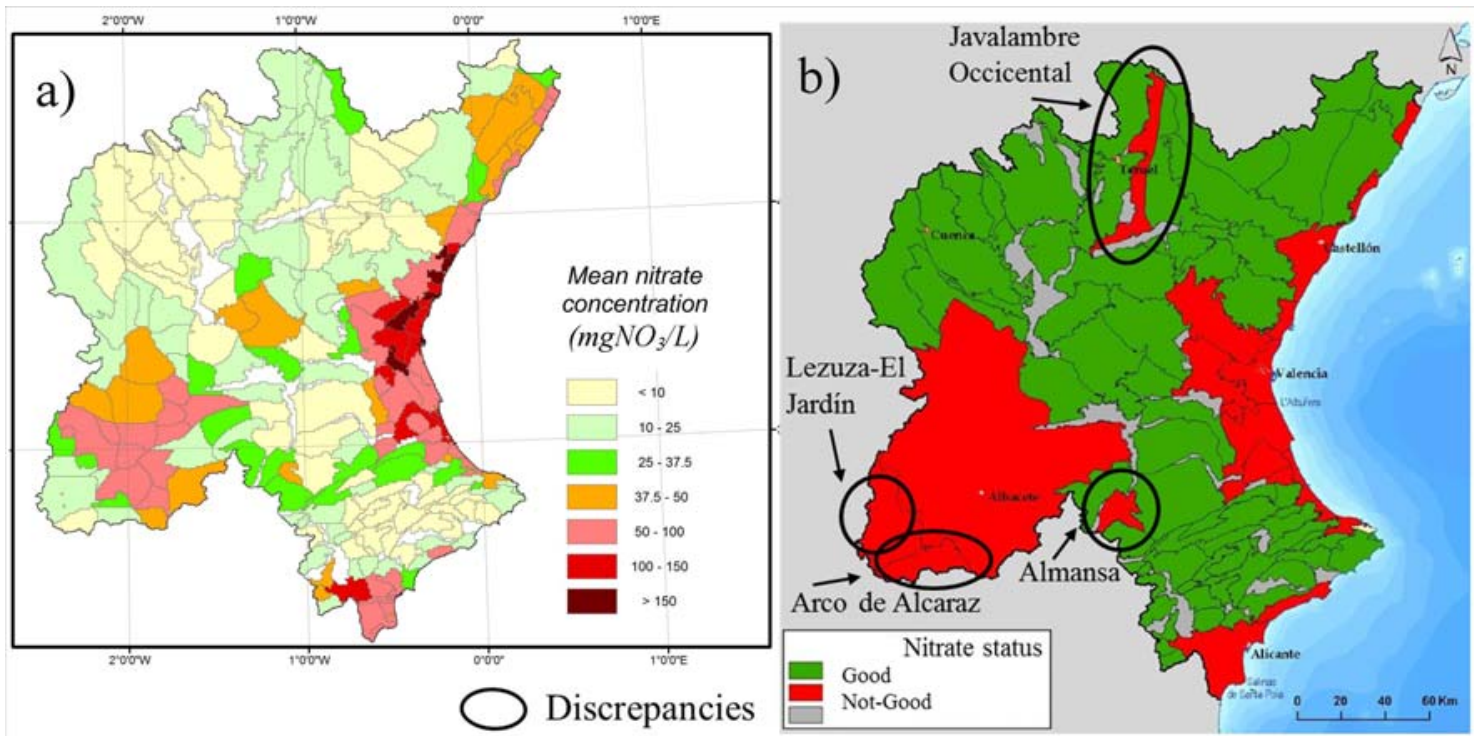

Fig. 6. a) Simulated mean nitrate concentration $\left(\mathrm{mgNO}_{3} / \mathrm{L}\right)$ in $\mathrm{GW}$ for the period 2010-2012. b) Nitrate status in the Júcar RBMP (Júcar, 2015).

Model results indicate that $26 \%$ of the annual averaged nitrogen surplus $(79,469$ $\mathrm{tN} /$ year) is volatilized from soil during the year (20,500 $\mathrm{tN} /$ year), additional to the $18,215 \mathrm{tN} /$ year volatilized during the nitrogen application. A large amount of nitrogen $(38,719 \mathrm{tN} /$ year) is emitted to the atmosphere $(21 \%$ of the total nitrogen input $-181,348$ 
$\mathrm{tN} /$ year). Shcherbak et al. (2014) indicates that Nitrous oxide $\left(\mathrm{N}_{2} \mathrm{O}\right)$ is a potent greenhouse gas (GHG) that also depletes stratospheric ozone and that Nitrogen $(\mathrm{N})$ fertilizer rate is the best single predictor of $\mathrm{N}_{2} \mathrm{O}$ emissions from agricultural soils, which are responsible for $\sim 50 \%$ of the total global anthropogenic flux, although it is a relatively imprecise estimator. Turner et al., 2015, indicates that $\mathrm{N}_{2} \mathrm{O}$ deleterious effects on the environment have prompted appeals to regulate emissions from agriculture, which represents the primary anthropogenic source in the global $\mathrm{N}_{2} \mathrm{O}$ budget.

$74 \%$ of the nitrogen surplus is carried by water $(58,965 \mathrm{tN} /$ year $), 31 \%$ of this $(18,193$ $\mathrm{tN} /$ year) by surface runoff and gets into the rivers. Finally, the remaining part $(69 \%$, $40,772 \mathrm{tN} /$ year) is carried by infiltration and reaches the aquifers. In the Júcar RBD, the average amount of nitrogen in soil is $8 \mathrm{kgN} / \mathrm{ha}$ and the average value in the unsaturated zone is $5 \mathrm{kgN} / \mathrm{ha}$. In the intensive agricultural areas the amount of nitrogen in soil mainly ranges from 20 to $40 \mathrm{kgN} / \mathrm{ha}$. 


\section{Future Groundwater Nitrate Concentration}

The nitrate concentration in each GW body and the measures needed to achieve the objective, are determined by simulating three future scenarios, from 2015 to 2039 to cover four water planning cycles (each water planning cycle in EU countries has 6 years). The scenarios are characterized by the doses of fertilization applied, as follows: 1) Baseline scenario: the nitrogen applied in the future is the same as last years (20082011), 2) Optimal scenario: the nitrogen applied corresponds to plants requirements (optimal doses); though, this scenario could imply a nitrogen deficit in the plant if the irrigation systems have not been modernized and 3) Trend Reversal and Improve (TR\&I) scenario: this is an intermediate scenario between previous scenarios.

The mean pressure in the Júcar RBD (table 2) varies between $18.5 \mathrm{kgN} / \mathrm{ha}(58.5$ $\mathrm{kgN} /$ ha-crop) in the baseline scenario, to $10.4 \mathrm{kgN} / \mathrm{ha}(32.9 \mathrm{kgN} /$ ha-crop$)$ in the optimal scenario, placing the investment scenario in an intermediate case with $14.4 \mathrm{kgN} / \mathrm{ha}$. The optimal scenario includes a nitrogen reduction of 35,890 $\mathrm{tN} /$ year $(20 \%$ reduction in the total inputs), which is produced basically with a minor application of mineral fertilizers of $26,600 \mathrm{tN} /$ year (reduction of $26 \%$ in the fertilizers application) and the subsequent minor atmospheric deposition of 2,650 $\mathrm{tN} /$ year (reduction of $14 \%$ in the atmospheric deposition). This reduction in the application of mineral fertilizers $(26 \%)$ produces a significant reduction in the nitrogen surplus of $44 \%$.

The implementation of the optimal scenario requires the modernization of the traditional irrigation systems, including the fertigation as the main measure to reduce nitrogen application in crops. This measure requires a large investment to modernize these irrigation systems. The Júcar River Basin Management Plan (RBMP) and the Programme of Measures (CHJ, 2015) includes the modernization of irrigation (drip irrigation) as one of the major measures to be applied in this Mediterranean area (area with water scarcity), aiming to achieve water savings and also other environmental objectives, such as reducing the use of fertilizers. The Júcar RBMP includes a government investment of 431 million euros between 2015 and 2027. 


\begin{tabular}{|c|c|c|c|}
\hline Scenario & Baseline & TR\&I & Optimal \\
\hline Nitrogen inputs (tN/year) (a) & 181,348 & 163,389 & 145,430 \\
\hline Nitrogen outputs (tN/year) & 101,879 & 101,292 & 100,705 \\
\hline Nitrogen surplus (tN/year) (b) & 79,469 & 62.097 & 44,725 \\
\hline Relative surplus (b/a) & 0.44 & 0.38 & 0.31 \\
\hline Local Nitrogen pressure (kgN/year/ha-crop) & 58.5 & 45.7 & 32.9 \\
\hline Gocal Nitrogen pressure (kgN/year/ha of crops and pastures) & 32.1 & 25.1 & 14.4 \\
\hline
\end{tabular}

Table 2. Characterization of future nitrogen scenarios.

The long time-lag in GW implies a large period of time to achieve the objective after the application of measures. This long time-lag is different in each aquifer, and mainly depends on the following: the aquifer extension, the aquifer hydrogeological characteristics, the thickness of the unsaturated zone and the water fluxes produced in the aquifer.

In the case of Buñol-Cheste GW body (Fig. 7), the nitrate concentration is stabilized around $100 \mathrm{mgNO}_{3} / \mathrm{L}$ under the baseline scenario and no recovery is produced. Under TR\&I scenario the trend is changed and a weak recovery is produced. Finally, only with the implementation of the optimal scenario the objective is reached; though around 25 years are required to reach this objective.

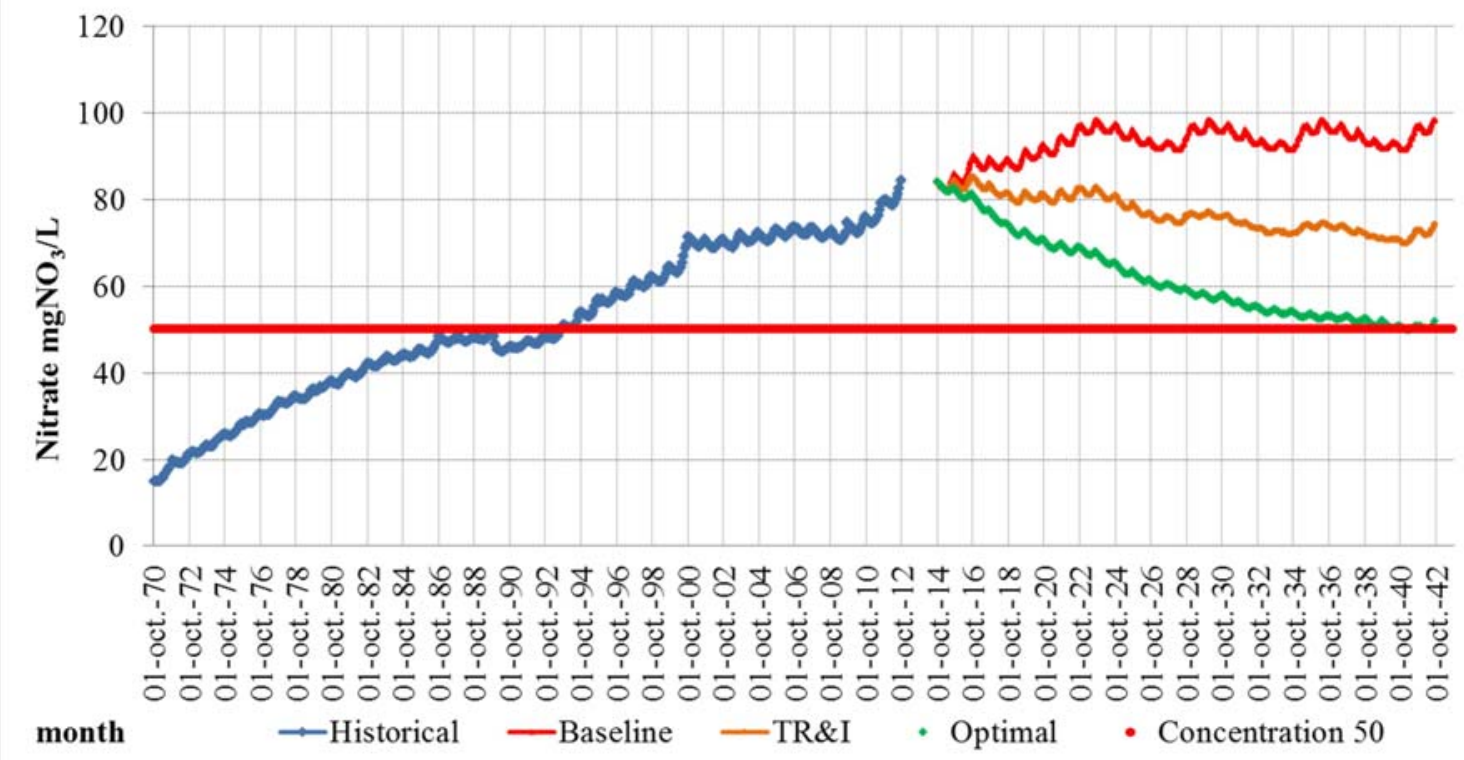

Fig. 7. Simulated mean nitrate concentration $\left(\mathrm{mgNO}_{3} / \mathrm{L}\right)$ for the historical period $1970-2011$ and the three future scenarios in the Buñol-Cheste GW body. 
$74 \%$ of $\mathrm{GW}$ bodies (67 of 90) reach the objective (nitrate concentration below 50 $\mathrm{mgNO}_{3} / \mathrm{L}$ ) in the year 2015 (Table 3). Four of these require the application of optimal doses of fertilizer to maintain the objective. The intensive irrigation areas of the Júcar RBD, coastal aquifers and Mancha Oriental aquifer, are the areas where the aquifers (23 out of 90) do not reach the objective in the year 2015 (Fig. 8a). In these areas the optimal scenario is required to achieve the objective the following cycles of 6 years (Fig. 8b). Besides, in four GW bodies additional measures (well as the application of optimal doses) are needed to reach the objective in the year 2039.

\begin{tabular}{|c|c|c|c|c|c|c|}
\hline Year to reach & Number GW bodies & ratio & Baseline & TR\&I & Optimal & Additional \\
\hline $\mathbf{2 0 1 5}$ & 67 & $74 \%$ & 62 & 0 & 5 & 0 \\
\hline $\mathbf{2 0 2 1}$ & 6 & $7 \%$ & 1 & 4 & 1 & 0 \\
\hline $\mathbf{2 0 2 7}$ & 9 & $10 \%$ & 0 & 0 & 9 & 0 \\
\hline $\mathbf{2 0 3 3}$ & 2 & $2 \%$ & 0 & 0 & 2 & 0 \\
\hline $\mathbf{2 0 3 9}$ & 6 & $7 \%$ & 0 & 0 & 2 & 4 \\
\hline Total GW bodies & $\mathbf{9 0}$ & $\mathbf{1 0 0} \%$ & $\mathbf{6 3}$ & $\mathbf{4}$ & $\mathbf{1 9}$ & $\mathbf{4}$ \\
\hline
\end{tabular}

Table 3. Number of GW bodies that reach the objective in each water planning cycle and measures required to accomplish it.

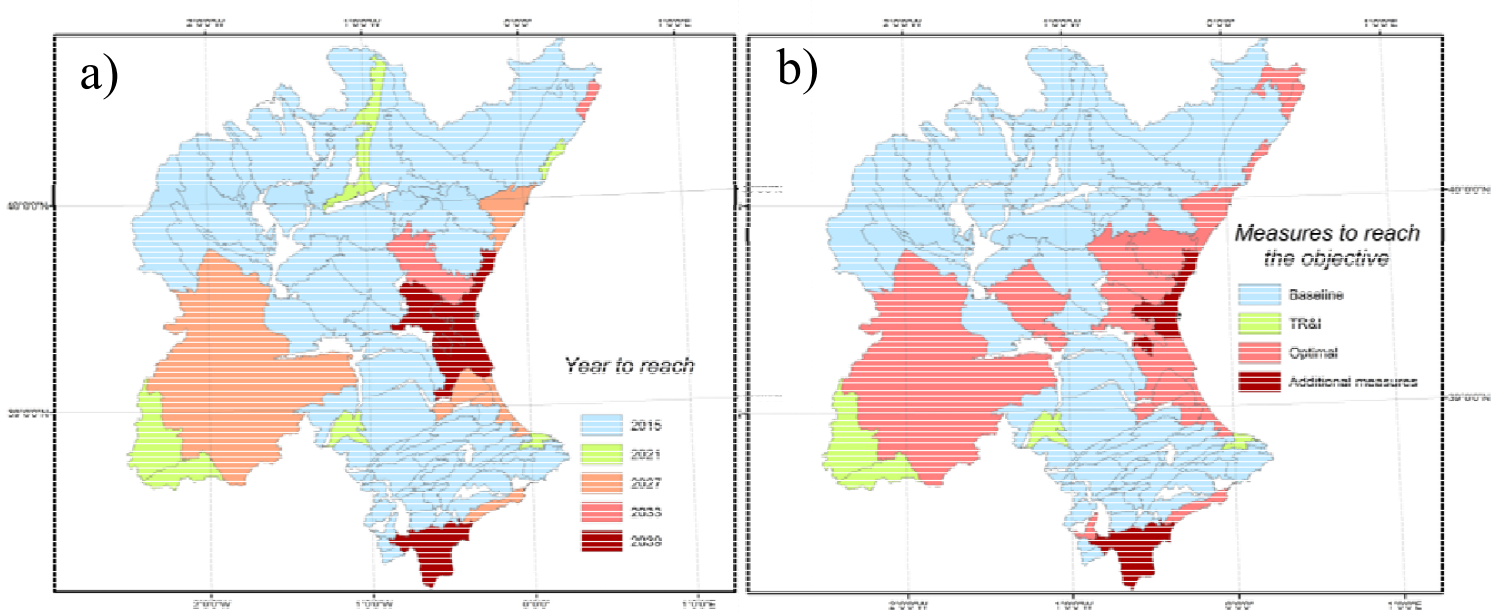

Fig. 8. a) Year to reach the environmental objectives in each GW body and b) measures required to achieve the objective in each GW body. 


\section{Conclusions}

This paper shows how to establish, the exemptions to achieve the nitrate objectives in the groundwater $(\mathrm{GW})$ bodies in a large river basin district according to the EU Water Framework Directive (WFD) and the measures to be applied to reach these objectives. The methodology presented is based on the use of the PATRICAL model that simulates the nitrogen cycle for a long period of time. The model and the methodology presented in this work is applicable to other river basins in the World and mainly in Europe, as it is demonstrated by the currently application to the entire Spanish territory.

The parameters are calibrated by fitting model results in each aquifer to the observed time series and, also, by fitting current average results to mean concentration in each aquifer. The model shows a satisfactory performance in $88 \%$ of the aquifers modelled that have high nitrate concentrations, and a good performance in $73 \%$ of the aquifers. Model results are validated with the official status assessment of the GW bodies made by the Júcar RBMP, where no significant discrepancies have been found. The nitrate model is quite robust because with only three parameters with the same value in the entire river basin, it fits the behaviour of aquifers in the entire river basin.

In the Júcar RBD, current nitrate concentration in $\mathrm{GW}$ reaches values higher than 50 $\mathrm{mgNO}_{3} / \mathrm{L}$, in a large number of $\mathrm{GW}$ bodies (23 of 90 ). The areas which currently have high values are the following: the coastal aquifers, where in some areas it reaches concentrations of $100-150 \mathrm{mg} / \mathrm{L}$, and the Mancha Oriental aquifer, where in some specific areas the nitrate concentration is higher than $50 \mathrm{mgNO}_{3} / \mathrm{L}$. In general terms, currently the nitrate concentration in GW has stabilized, with no trend; only a few deep aquifers, due to their major long time-lag, show some upward trend such as Medio Palancia or Buñol-Cheste aquifer.

The horizons in which nitrate WFD objectives are reached in each GW body and the measures needed to do it were determined by simulating three future scenarios from the year 2015 to 2039, covering four water planning cycles of 6 years. The implementation of modernized irrigation systems, including the fertigation systems to apply the fertilizers, could reduce the use of fertilizers and allows to meet the WFD objectives in the following planning cycles. The reduction in the application of mineral fertilizers (26\% optimal scenario) produces a significant reduction in the nitrogen surplus $(44 \%$ 
optimal scenario). Based on the $23 \mathrm{GW}$ bodies that do not currently meet the objectives, 15 of them could achieve the objective before the year 2027 and the rest before the year 2039. The more or less prolonged period of time required to comply with the objectives, depends on the long time-lag of each aquifer.

\section{Acknowledgements}

The authors would like to sincerely thank the Júcar River Basin Authority, Confederación Hidrográfica del Júcar, for providing data and using the model.

\section{References}

Aquilina L., Vergnaud-Ayraud V., Labasque T., Bour O., Molénat J., Ruiz L., Montety V. de, Ridder J. De, Roques C., Longuevergne L. (2012) Nitrate dynamics in agricultural catchments deduced from groundwater dating and long-term nitrate monitoring in surface and groundwaters. Science of the Total Environment 435-436 (2012) 167-178.

Beaujouan V., Durand P., Ruiz L., Aurousseau P., Cotteret G. (2002) A hydrological model dedicated to topography-based simulation of nitrogen transfer and transformation: rationale and application to the geomorphology-denitrification relationship. Hydrological Processes 16, 493-507

Berka C., Schreier H., Hall K. (2001) Linking water quality with agricultural intensification in a rural watershed. Water, Air and Soil Pollution 127, 389-401.

Blecken M., Bakken L. (1997) The Anthropogenic Nitrogen Cycle in Norway. Cab International.

Boyer E., Goodale C., Jaworski N., Howarth R. (2002) Anthropogenic nitrogen sources and relationships to riverine nitrogen export in the northeastern USA. Biogeochemistry (57/58), 137-169.

Breuer L., Vaché K., Julich S.H.-G.F. (2008) Current concepts in nitrogen dynamics for mesoscale catchments. Hydrological Sciences Journal 53 (5).

Brisson N., Mary B., Ripoche D., Jeuffroy M.H., Ruget F., Nicoullaud B., Gate P., Devienne-Barret F., Antonioletti R., Durr C., Richard G., Beaudoin N., Recous S., Tayot X., Plenet D., Cellier P., Machet J.M., Meynard J.M. and Delécolle R. (1998) STICS: a generic model for the simulation of crops and their water and nitrogen balances. I. Theory and parameterization applied to wheat and corn. Agronomie (Paris); 18(5-6):311-346.

CHJ (2015) (Júcar Water Agency) Júcar River Basin Plan. Demarcación hidrográfica del júcar. Confederación Hidrográfica del Júcar, Ministry of Agriculture, Food and Environment, Spain. 
Deng H., Wang L., Liu J., Zou J., Li D., Zhou Q., and Huang J. (2011). Mathematical and Computer Modelling 54(3-4):956-964 (2011)

Dupas R., Parnaudeau V., Reau R., Jeuffroy M., Durand P., Gascuel-Odoux C. (2015) Integrating local knowledge and biophysical modeling to assess nitrate losses from cropping systems in drinking water protection areas. Environ. Model. Softw. 69 (2015) 101-110. doi: 10.1016/j.envsoft.2015.03.009.

EC (1991) (European Community). Council Directive of 12 December 1991 concerning the protection of waters against pollution caused by nitrates from agricultural sources (91/676/EEC). 1991.

EC (2000) (European Community). Directive 2000/60/EC of the European Parliament and of the Council, of 23 October 2000, establishing a framework for Community action in the field of water policy. Official Journal of the European Commission, L 327/1,22.12.2000. 2000.

EC ( 2006) (European Community). Directive 2006/118/EC of the European Parliament and of the Counci,l of 12 December 2006 on the protection of groundwater against pollution and deterioration

Ferrant S., Oehler F., Durand P., Ruiz L., Salmon-Monviola J., Justes E., Dugast P., Probst A., Probst J.L., Sanchez-Perez J.M. (2011) "Understanding nitrogen transfer dynamics in a small agricultural catchment: Comparison of a distributed (TNT2) and a semi distributed (SWAT) modelling approaches", Journal of Hydrology, 406, pages 1-15.

Ferrer J, Pérez-Martín MA, Jiménez S, Estrela T, Andreu J (2012) GIS based models for water quantity and quality assessment in the Júcar River Basin, Spain, including climate change effects. Science of the Total Environment. doi:10.1016/j.scitotenv.2012.08.032

Flipo N., Even S., Poulin M., Thery S., Ledoux E. (2007) Modeling nitrate fluxes at the catchment scale using integrated tool cawaqs. Science of The Total Environment 375 (1-3), 69-79

Galloway J.N., Dentener F.J., Capone D.G., Boyer E.W., Howarth R.W., Seitzinger S.P., Asner G.P., Cleveland C.C., Green P.A., Holland E.A., Karl D.M., Michaels A.F., Porter J.H., Townsend A.R., Vöosmarty C.J. (2004) Nitrogen cycles: past, present, and future. Biogeochemistry; 70(2):153-226.

Gillingham A. and Thorrold B. (2000) A review of New Zealand research measuring phosphorus in runoff from pasture. Journal of Environmental Quality 29, 88-96.

Hajhamad L. and Almasri M. (2009) Assessment of nitrate contamination of groundwater using lumpedparameter models. Environ. Model. Softw. 24 (2009) 1073-1087. doi:10.1016/j.envsoft.2009.02.014

Heffer P. (2012) Nutrient Supply and Management. Capturing Opportunities and Overcoming Obstacles in Australian Agronomy". Edited by I. Yunusa. Proceedings of 16th Australian Agronomy Conference 2012, 14-18 October 2012, Armidale, NSW.

Houser J.N. and Ricahrson W.B. (2010) Nitrogen and phosphorus in the Upper Mississippi River: transport, processing, and effects on the river ecosystem. Hydrobiologia (2010) 640:71-88 DOI 10.1007/s10750-009-0067-4. 
Howarth R., Billen G., Swaney D., Townsend A., Jaworski N., Lajtha K., Downing J., Elmgren R., Caraco N., Jordan T., Berendse F., Freney J., Kudeyarov V., Murdoch P., Zhao-Liang Z. (1996) Regional nitrogen budgets and riverine N\&P fluxes for the drainages to the North Atlantic Ocean: natural and human influences. Biogeochemistry 35, 75-139.

Huan H, Wang J, Teng Y. (2012) Assessment and validation of groundwater vulnerability to nitrate based on a modified DRASTIC model: a case study in Jilin City of northeast China. Sci Total Environ. 2012 Dec 1;440:14-23. doi: 10.1016/j.scitotenv.2012.08.037. Epub2012 Sep 10.

Kuhr P, Haider J., Kreins P., Kunkel R., Tetzlaff B., Vereecken H. and Wendland F. (2015) Model Based Assessment of Nitrate Pollution of Water Resources on a Federal State Level for the Dimensioning of Agro-environmental Reduction Strategies The North Rhine-Westphalia (Germany) Case Study. Water Resour Manage (2013) 27:885-909. DOI 10.1007/s11269-012-0221-z

Lake I.R., Lovett A.A., Hiscock K.M., Betson M., Foley A., Sünnenberg G., Evers S., Fletcher S. (2003) Evaluating factors influencing groundwater vulnerability to nitrate pollution: developing the potential of GIS. J Environ Manage 2003;68(3):315-28.

Lasserre F, Razack M, Banton O. (1999) A GIS-linked model for the assessment of nitrate contamination in groundwater. J Hydrol 1999;224(3-4):81-90.

Leip A., Britz W., Weiss F. de Vries W. (2011) Farm, land, and soil nitrogen budgets for agriculture in Europe calculated with CAPRI. Environmental Pollution 159 (2011) $3243 e 3253$. doi:10.1016/j.envpol.2011.01.040

Liu S., Tucker P., Mansell M., Hursthouse A. (2005) Development and application of a catchment scale diffuse nitrate modelling tool. Hydrological Processes 19 (13), 2625-2639.

Lunn RJ, Adams R, Mackay R, Dunn SM. (1996) Development and application of a nitrogen modelling system for large catchments. J Hydrol 1996;174(3-4):285-304.

Mangold, D., Tsang, C. (1991) A summary of subsurface hydrological and hydrochemical models. Reviews of Geophysics 29, 51-79

Martin C., Aquilina L., Gascuel-Odoux C., Molenat J., Faucheux M., Ruiz L. (2004). Seasonal and interannual variations of nitrate and chloride in stream waters related to spatial and temporal patterns of groundwater concentrations in agricultural catchments. Hydrological Processes 18, 1237-1254.

Martínez-Bastida J.J., Arauzo M., Valladolid M. (2010) Intrinsic and specific vulnerability of groundwater in central Spain: the risk of nitrate pollution. Hydrogeology Journal (2010)18:681-698.

Molenat J., Durand P., Gascuel-Odoux C., Davy P., Gruau G. (2002) Mechanisms of nitrate transfer from soil to stream in an agricultural watershed of French Brittany. Water, Air, and Soil Pollution 133, 161-183. 
Monaghan R., Paton R., Smith L., Drewry J., Littlejohn R. (2005) The impacts of nitrogen fertilisation and increased stocking rate on pasture yield, soil physical condition and nutrient losses in drainage from a cattle-grazed pasture. New Zealand Journal of Agricultural Research 48, 227-240.

Moriasi DN, Arnold JG, Van Liew MW, Bingner RL, Harmel RD, Veith TL (2007) Model evaluation guidelines for systematic quantification of accuracy in watershed simulations. Transactions of the American Society of Agricultural and Biological Engineers. 50(3):885-900, doi:10.13031/2013.23153

Narula K.K. and Gosain A.K. (2012) Modeling hydrology, groundwater recharge and non-point nitrate loadings in the Himalayan Upper Yamuna basin. Science of the Total Environment $468-469$ (2013) S102-S116

Neill M. (1989) Nitrate concentrations in river waters in the south-east of Ireland and their relationship with agricultural practice. Water Resources Research 23 (11), 1339-1355.

Outram F.N., Cooper R.J., Sünnenberg G., Hiscock K.M., Lovett A.A. (2016), Antecedent conditions, hydrological connectivity and anthropogenic inputs: Factors affecting nitrate and phosphorus transfers to agricultural headwater streams, Science of The Total Environment, Volumes 545-546, 1 March 2016, Pages 184-199, ISSN 0048-9697, http://dx.doi.org/10.1016/j.scitotenv.2015.12.025.

Pacheco F.A.L., Sanches Fernandes L.F. (2016) Environmental land use conflicts in catchments: A major cause of amplified nitrate in river water, Science of The Total Environment, Volumes 548-549, 1 April 2016, Pages 173-188, ISSN 0048-9697, http://dx.doi.org/10.1016/j.scitotenv.2015.12.155.

Pérez-Martín MA, Estrela T, del-Amo P (2012) Definition of Environmental Objectives in Relation with Nitrate Pollution in the Aquifers of Spain. Simulation Model and Scenarios used. International Congress on Environmental Modelling and Software (iEMSs2012), Leipzig

Pérez-Martín MA, Estrela T, Andreu J and Ferrer J. (2014) Modeling Water Resources and RiverAquifer Interaction in the Júcar River Basin, Spain. Water Resour Manage (2014) 28:4337-4358 DOI 10.1007/s11269-014-0755-3

Quinn P. (2004) Scale appropriate modelling: representing cause-and-effect relationships in nitrate pollution at the catchment scale for the purpose of catchment scale planning. J Hydrol 2004;291(34):197-217

Reynolds, B., Edwards, A. (1995) Factors influencing dissolved nitrogen concentrations and loadings in upland streams of the UK. Agricultural Water Management 27, 181-202.

Rios J.F., Ye M., Wang L., Lee P.Z., Davis H and Hicks R. (2013) ArcNLET: AGIS-based software to simulate ground water nitrate load from septic systems to surface water bodies. Computers \& Geosciences 52 (2013) 108-116. 
Ruiz L., Abiven S., Martin C., Durand P., Beaujouan V., Molenat J. (2002) Effect on nitrate concentration in stream water of agricultural practices in six small catchments in brittany: II. Temporal variations and mixing processes. Hydrology \& Earth System Sciences 6 (3), 507-513.

Shcherbak I., Millar N., and Robertson G.P. (2014) Global metaanalysis of the nonlinear response of soil nitrous oxide (N2O) emissions to fertilizer nitrogen PNAS 2014111 (25) 9199-9204; published ahead of print June 9, 2014, doi:10.1073/pnas.132243411

Shen YJ; Lei HM; Yang DW; Kanae S. (2011) Effects of agricultural activities on nitrate contamination of groundwater in a Yellow River irrigated region. Water Quality: Current Trends And Expected Climate Change Impacts: IAHS Publication, 2011,348 (1):73-80.

Styczen M. and Storm B. (1995) Modeling the effects of management practices on nitrogen in soils and groundwater. In: Bacon (Ed.), Nitrogen Fertilization in the Environment, vol. 14. ISBN 0-8247-89946 CRC Press, pp. 537-564.

Turner P.A., Griffis T.J., Lee X., Baker J.M., Venterea R.T., Wood J.D. (2015) Indirect nitrous oxide emissions from streams within the US Corn Belt scale with stream order PNAS 2015112 (32) 98399843; published ahead of print July 27, 2015, doi:10.1073/pnas.1503598112

USEPA (2000) (Environmental Protection Agency) Drinking Water Standards and Health Advisories. U.S. Environmental Protection Agency, Office of Water, 822-B-00-001, 12 pp.

USEPA (2004) (Environmental Protection Agency) Consumer factsheet on: nitrates/nitrites. Washington, DC: US Environmental Protection Agency; 2004. Available from URL: http://www.epa.gov/safewater/dwh/c-ioc/nitrates.html

USEPA (2007) (Environmental Protection Agency) Nitrates and Nitrites TEACH Chemical Summary.

Vachaud G., Vauclin M., Addiscott T. (1993) Solute transport in the vadose zone: a review of models. In: Avogadro, A., Ragaini, R. (Eds.), Technologies for Environmental Cleanup: Soil and Groundwater, ECSC-EEC-EAEC, Bruxelles-Luxembourg, pp. 157-185.

Vanclooster M, Viaene P, Diels J, Feyen J.(1995) A deterministic evaluation analysis applied to an integrated soil-crop model. Ecol Model 1995;81(1-3):183-95.

Vitousek P.M., Mooney H.A., Lubchenco J., and Melillo J.M. (1977). Human Domination of Earth's Ecosystems. Science 25 July 1997: 277 (5325), 494-499. [DOI:10.1126/science.277.5325.494]

Wade A., Durand P., Beaujouan V., Wessel W., Raat K., Whitehead P., Butterfield D., Rankinen K., Lepisto A., (2004) A nitrogen model for European catchments: Inca. New model structure and equations. Hydrology \& Earth System Sciences 8 (4), 858-859.

Wang L, Stuart M E, Bloomfield J P, Butcher A S, Gooddy D C, McKenzie A A, Lewis M A and Williams A T. 2012. Prediction of the arrival of peak nitrate concentrations at the water table at the regional scale in Great Britain. Hydrological Processes. 26, 226-239; 
Wang L, Butcher AS, Stuart ME, Gooddy DC and Bloomfield JP. 2013. The nitrate time bomb: a numerical way to investigate nitrate storage and lag time in the unsaturated zone. Environmental Geochemistry and Health 35, 5, 667-681.

Wang L., Stuart M.E., Lewis M.A., Ward R.S., Skirvin D., Naden P.S., Collins A.L., Ascott M.J. (2016) The changing trend in nitrate concentrations in major aquifers due to historical nitrate loading from agricultural land across England and Wales from 1925 to 2150, Science of The Total Environment, Volume 542, Part A, 15 January 2016, Pages 694-705, ISSN 0048-9697, http://dx.doi.org/10.1016/j.scitotenv.2015.10.127.

Watson C., Foy R. (2001) Environmental impacts of nitrogen and phosphorus cycling in grassland systems. Outlook on Agriculture 30, 117-127.

Webb B., Walling D. (1985) Nitrate behavior in streamflow from a grassland catchment in Devon, UK. Water Research 19 (8), 1005-1016.

Whitehead P., Johnes, P., Butterfield, D. (2002a) Steady state and dynamic modelling of nitrogen in the River Kennet: impacts of land use change since the 1930s. Science of The Total Environment 282/283, 417-435.

Whitehead P., Lapworth D., Skeffington R., Wade A. (2002b) Excess nitrogen leaching and C/N decline in the tillingbourne catchment, southern England. Hydrology \& Earth System Sciences 6, 455-466.

Zhang D., Chen X., Yao H. (2016) SWAT-CSenm: Enhancing SWAT nitrate module for a Canadian Shield catchment, Science of The Total Environment, Volume 550, 15 April 2016, Pages 598-610, ISSN 0048-9697, http://dx.doi.org/10.1016/j.scitotenv.2016.01.109. 


\section{Appendix. Model formulation}

Summary of model variables is included in Table A1 and model parameters description is included in Table A1

$<$ Table A1 $>$

\section{Nitrogen Balance in Soil}

Nitrogen in soil $N s o i l_{i j, t}(\mathrm{kgN} / \mathrm{ha})$, in cell "ij" in month " $t$ ", is obtained by mass balance.

$$
\operatorname{Nsoil}_{i j, t}=\left(\text { Nsoil }_{i j, t-1}+N s u r_{i j, t}-\text { Nleach }_{i j, t}\right) \cdot e^{-k d e n}
$$

Nsoil $_{i j, t-1}$ is the amount of nitrate in soil from previous month, $N \operatorname{sur}_{i j, t}(\mathrm{kgN} / \mathrm{ha})$ is the nitrogen surplus generated in this month, kden is the denitrification constant and Nleach $_{i j, t}(\mathrm{kgN} / \mathrm{ha})$ is the nitrogen leached from soil, which is computed by:

$$
\text { Nleach }_{i j, t}=\left(\text { soil }_{i j, t-1}+N \operatorname{sur}_{i j, t}\right) \cdot\left(1-e^{\left(-k s \cdot \frac{\left(W a^{*} i j, t\right)}{S w m a x}\right)}\right)
$$

Where: $k s$ is the nitrate transfer coefficient of soil, Swmax $i j$ is the water soil storage capacity $(\mathrm{mm}), W a_{i j, t}$ is the hydrological surplus $(\mathrm{mm})$ corresponding to the sum of surface runoff, infiltration and water returns from irrigation excess.

The nitrogen is leached from soil by the surface runoff $(\mathrm{mm}) \operatorname{Rsup}_{i j, t}$, as superficial nitrogen $\operatorname{Nsup}_{i j, t}(\mathrm{kgN} / \mathrm{ha})$, and the infiltration $(\mathrm{mm}) \operatorname{Rinf}_{i j, t}$, as infiltrate nitrogen $\operatorname{Ninf}_{i j, t}$ ( $\mathrm{kgN} / \mathrm{ha})$, both with the same nitrate concentration:

$$
\begin{aligned}
& \operatorname{Nsup}_{i j, t}=\text { Nleach }_{i j, t} \cdot \frac{\operatorname{Rsup}_{i j, t}}{W a^{*}{ }^{*}, t} \\
& \operatorname{Ninf}_{i j, t}=\text { Nleach }_{i j, t} \cdot \frac{\operatorname{Rinf}_{i j, t}}{W a^{*}{ }_{i j, t}}
\end{aligned}
$$




\section{Nitrogen Balance in the Unsaturated Zone}

Infiltrated nitrogen reaches the unsaturated zone, where it is stored $N u z_{i j, t}(\mathrm{kgN} / \mathrm{ha})$. The balance of nitrate stored in the unsaturated zone has the following expression:

$$
N u z_{i j, t}=N u z_{i j, t-1}+N i n f_{i j, t}-N u z i n f_{i j, t}
$$

A part of nitrate stored is washed by infiltration and reaches to the aquifer Nuzinf $i_{j, t}$ $(\mathrm{kgN} / \mathrm{ha})$, it is computed as follows:

$$
N u z i n f_{i j, t}=\left(N u z_{i j, t-1}+N i n f_{i j, t}\right) \cdot\left(1-e^{\left(-k u z \cdot \frac{\operatorname{Rinf}_{i j, t} \cdot \operatorname{Imax}_{i j}}{d_{i j, t}+1}\right)}\right)
$$

Where: $k u z$ is the nitrate transfer coefficient in the unsaturated zone $\left(\mathrm{mm}^{-1}\right), \operatorname{Imax}_{i j}$ is the monthly infiltration capacity $(\mathrm{mm}), d_{i j, t}$ is the depth of water table $(\mathrm{mm})$.

\section{Nitrogen Balance in the Aquifer}

The aquifer is considered like a dispersive storage, so the nitrogen is totally mixed with the water stored. Nitrate concentration in the aquifer $C N a q_{k, t}$ is obtained by:

$$
C N a q_{k, t}=4.43 \cdot \frac{N a q_{k, t-1}+N a q I_{k, t}}{W a q_{k, t-1}+R n_{k, t}}
$$

Where previous nitrogen is obtained by:

$$
N a q_{k, t-1}=C N f a q_{k, t-1} \cdot W a q_{k, t-1}
$$

and the nitrogen that reaches the aquifer $N a q I_{k, t}$ is the sum of the distributed nitrogen above the aquifer,

$$
\operatorname{NaqI}_{k, t}=\sum_{\text {aquifer_ }}^{i, j} \operatorname{Nuzinf}_{i j, t} .
$$

Distributed nitrogen discharges to the river $N a q O d_{i j, t}$ is obtained by:

$$
\operatorname{NaqOd}_{i j, t}=\frac{1}{4.43} \cdot \mathrm{CNaq}_{k, t} \cdot \operatorname{Rsub}_{i j, t}
$$




\section{Routing Module and River Losses}

Nitrogen from aquifers is joined to nitrogen carried by surface runoff $N s u p_{i j, t}$ and the point pollution discharges $N d i s c h_{i j, t}$, which together become the total content of nitrate in the surface network.

$$
\operatorname{Ntotal}_{i j, t}=\operatorname{NaqOd}_{i j, t}+\operatorname{Nsup}_{i j, t}+\operatorname{Ndisch}_{i j, t}
$$

The total nitrate is accumulated in the drainage network $N n e t_{i j, t}{ }^{\prime}$ using the digital elevation model (DEM). Monthly nitrate concentration in the river $\mathrm{CNnet}^{\prime}{ }_{i j, t}\left(\mathrm{mg} \mathrm{NO}_{3}{ }^{-}\right.$ (L) is obtained dividing the nitrate accumulation and river flows $R_{T n e t}{ }^{\prime} i, t$.

$$
\text { CNnet }_{i j, t}=4.43 \cdot{ }^{\text {Nnet }^{\prime}}{ }_{i j, t}^{\prime} / \text { RTnet }_{i j, t}^{\prime}
$$

Nitrogen infiltrated from rives is obtained by:

$$
N L_{i j, t}=\frac{1}{4.43} \text { CNnet }_{i j, t} \cdot R L_{i j, t}
$$

\section{Groundwater Transfer Module}

Final nitrate concentration in the aquifer $\mathrm{k}, \mathrm{CNfaq}_{k, t}$, is the relation between total nitrogen inputs and total available water, as follows:

$$
C N f a q_{k, t}=4.43 \cdot \frac{W a q_{k, t} \cdot C N a q_{k, t}+N a q R L_{k, t}+\sum_{r=1}^{n} F l_{r k, t} \cdot C N a q_{r, t}}{W a q_{k, t}+R L a q_{k, t}+\sum_{r=1}^{n} F l_{r k, t}}
$$

Where, $N a q R L_{k, t}$ is the total nitrogen infiltrated into the aquifer by the river losses $R L a q_{k, t}, F l_{r k, t}$ is the lateral flows between all the aquifers $(n)$ to the aquifer $k$. 